\title{
In vitro Antimicrobial Activity Evaluation of Newly Synthesized Furochromone Schiff Base Complexes
}

\author{
M. M. E. Shakdofa ${ }^{1,2}$, H. A Mousa 2 , A. A. labib $^{2}$, A. S. Abd El-All ${ }^{3}$, F. A. Bassyouni ${ }^{3}$ \\ ${ }^{1}$ Department of Chemistry, Faculty of Science and Arts, Khulais, University of Jeddah, \\ Saudi Arabia \\ ${ }^{2}$ Department of Inorganic Chemistry, National Research Centre, El-Bohouth St., P.O. \\ 12622, Dokki, Cairo, Egypt \\ ${ }^{3}$ Department of Natural and Microbial Products, National Research Centre, El- \\ Bohouth St., P.O. 12622, Dokki, Cairo, Egypt
}

\begin{abstract}
SERIES of $\mathrm{VO}^{\mathrm{II}}, \mathrm{Ni}^{\mathrm{II}}, \mathrm{Cu}^{\mathrm{II}}, \mathrm{Co}^{\mathrm{II}}, \mathrm{Mn}^{\mathrm{II}}, \mathrm{Cd}^{\mathrm{II}}$ and $\mathrm{Zn}^{\mathrm{II}}$ complexes of new Schiff base ligand resulting form 4-aminoantipyrine and Furobenzopyrone were prepared. The structure of newly synthesized compounds (1-8) was proven by studying their elemental analyses, spectral data (IR, NMR, UV-vis), molar conductivity and magnetic susceptibility. In addition the in vitro antimicrobial activity of all compounds was examined. The results cleared that nickel and zinc complexes exhibited promising activity compared with standard drug (chloramphenicol).
\end{abstract}

Keywords: Schiff base, Metal complexes, Antimicrobial, Furochromone.

\section{Introduction}

Furochromones ( Khellin and visnagin) are one of the important heterocyclic compounds that need to be studied due to their remarkable biological activity as a potent antimicrobial agent and its derivatives showed remarkable antimicrobial activity against bacteria and Candida species,[1-3] phototherapeutic[4] potential, antispasmodic action, [5] anti-Inflammatory[3] analgesic and anticonvulsant effect, $[6,7]$ in vitro cytotoxicity [8] and as antiviral.[9-11] In addition to its folk use, recently, pharmaceutical companies realized the pharmacological effect of furochromones as coronary vasodilator drug and to treat a variety of diseases as bronchial asthma, angina pectoris, and also some furochromen derivatives are component for the treatment of chronic skin or eye diseases, furochromone drugs in market are used in ophthalmic and in treatment of dermatological diseases.[12] Recently, it has been known that khellin analogs with lower toxicity and better efficacy have ability to curative vitiligo and psoriasis,[13-17] so most current researches are focusing on their use in the treatment of vitiligo. Also, visnagin has own biological activity of reducing blood pressure by inhibiting calcium influx into the cell as a vasodilator, and neuro protective effect which are associated with its anti-inflammatory effects.[18, 19] Eventually it's announced that radio iodinated khellin is used in imaging urinary tract.[20]

In view of the above mentioned facts, and as resumption to our work on the preparation of bioactive metal complexes,[21-26] the present work is devoted to synthesize, characterize and evaluate antimicrobial activity of some furochromone Schiff base complexes.

\section{Experimental}

Chemistry

Materials

All the reagents employed for the preparation of the ligand and its complexes were synthetic grade and used without further purification. All other chemicals and reagents used in this biological study were of analytical grade and 
purchased from Sigma-Aldrich Chemical Co. (St. Louis, MO, USA). 9-dimethoxy-5-oxo5H-furo[3,2-g]chromene-6-carbaldehyde was prepared by a published Vilsmier-Haack reaction. [27-30]

\section{Physical Measurements}

The ligand and its metal complexes were analyzed for $\mathrm{C}, \mathrm{H}, \mathrm{N}$ and $\mathrm{S}$ on VARIO EL III GERMANY at the Microanalytical center, Faculty of Science Cairo University. IR spectra of the ligand and its metal complexes was measured using $\mathrm{KBr}$ discs with a Jasco FT/IR 300E Fourier transform infrared spectrophotometer covering the range $400-4000 \mathrm{~cm}^{-1}$. Electronic spectra in the 200-1100 $\mathrm{nm}$ regions were recorded on a on a SHMADZU 2600 spectrophotometer using $1 \mathrm{~cm}$ quartz cells taking DMF as solvent. The thermal analysis (TG) was carried out on an Shimadzu DT-30 thermal analyzer from room temperature to $800{ }^{\circ} \mathrm{C}$ at a heating rate of $10^{\circ} \mathrm{C} /$ min. Magnetic susceptibilities were measured by the Gouy method at $25^{\circ} \mathrm{C}$ on a Johnson Matthey Magnetic Susceptibility Balance using mercuric tetrathiocyanatocobaltate(II) as the magnetic susceptibility standard. Diamagnetic corrections were estimated from Pascal's constant.[31] The magnetic moments were calculated from the equation: $\mu_{\text {eff. }}=2.8 \sqrt{\chi_{M}^{\text {corr }} . T}$. Molar conductance was measured on a Tacussel type $\mathrm{CD}_{6} \mathrm{NG}$ conductivity bridge using $10^{-3} \mathrm{M}$ DMF solutions. NMR spectrum was obtained on a JEOL EX-270 MHz spectrometers.

\section{Synthesis of compounds}

Synthesis of ligand: The ligand, 4-((4,9-dimethoxy-5-oxo-5 H-furo[3,2-g] chromen-6-yl)-methyleneamino)-1,5-dimethyl-2phenyl-1H-pyrazol-3(2H)-one (L) was prepared by refluxing an equimolar amounts of 4-amino1,5-dimethyl-2-phenyl-1-H-pyrazol-3(2H)-one (203 mg, $1.0 \mathrm{mmol})$ in $20 \mathrm{~mL}$ hot methanol $\left(60^{\circ} \mathrm{C}\right)$ with (274 mg, $1.0 \mathrm{mmol}$ ) of 4,9-dimethoxy-5-oxo$5 \mathrm{H}$-furo[3,2-g]chromene-6-carbaldehyde in 50 $\mathrm{mL}$ hot methanol $\left(60^{\circ} \mathrm{C}\right)$ in presence of 3 drops of glacial acetic acid. The mixture was refluxed while stirring for $3 \mathrm{~h}$. then the solvent was evaporated to $30 \mathrm{~mL}$. The solid product was filtered off, washed with cold methanol, crystallization from ethanol and dried in oven $\left(60^{\circ} \mathrm{C}\right)$ for $4 \mathrm{~h}$. Yield $(312 \mathrm{mg}$, $68 \%$ ), color is dark yellow, m.p. 163, Elemental analysis for $\mathrm{C}_{25} \mathrm{H}_{21} \mathrm{~N}_{3} \mathrm{O}_{6}$ (459.46): Found (calcd) $\% \mathrm{C} 65.35(64.80), \% \mathrm{H} 4.61 \quad(5.00), \% \mathrm{~N} 9.15$ (8.70). IR ( $\left.\mathrm{KBr}, \mathrm{cm}^{-1}\right), 1680,1652 \mathrm{v}(\mathrm{C}=\mathrm{O}), 1625$ $v(\mathrm{C}=\mathrm{N}) .{ }^{1} \mathrm{H}-\mathrm{NMR}\left(270 \mathrm{MHz}, \mathrm{DMSO}-d_{6}\right): 8.79(\mathrm{~s}$, $\left.1 \mathrm{H},{ }^{1} \mathrm{C}-H\right), 7.85\left(\mathrm{~s}, 1 \mathrm{H},{ }^{22} \mathrm{C}-H\right), 7.50\left(\mathrm{~d}, 1 \mathrm{H},{ }^{15} \mathrm{C}-\right.$ $\mathrm{H}), 7.07\left(\mathrm{~d}, 1 \mathrm{H},{ }^{14} \mathrm{C}-\mathrm{H}\right), 7.47\left(\mathrm{~m}, 2 \mathrm{H},{ }^{31,33} \mathrm{C}-\mathrm{H}\right)$, 7.37 (d, $\left.2 \mathrm{H},{ }^{30,34} \mathrm{C}-\mathrm{H}\right), 7.30\left(\mathrm{t}, 1 \mathrm{H},{ }^{35} \mathrm{C}-\mathrm{H}\right), 4.10$ (s, $\left.3 \mathrm{H}, \mathrm{O}^{28} \mathrm{CH}_{3}\right), 2.42\left(\mathrm{~s}, 3 \mathrm{H}, \mathrm{N}-{ }^{10} \mathrm{CH}_{3}\right), 3.14(\mathrm{~s}, 3 \mathrm{H}$, C- ${ }^{7} \mathrm{CH}_{3}$ ). UV. vis. $1 \mathrm{~cm}$ quartz cells, DMSO) 260, 290, 335, 385 .

Synthesis of metal complexes: The metal complexes (2-8), were prepared by adding drop wisely a hot ethanolic solution $\left(50 \mathrm{~mL}, 60^{\circ} \mathrm{C}\right)$ of $1 \mathrm{mmol}$ of the following metal salts $\mathrm{VOSO}_{4} \cdot 3 \mathrm{H}_{2} \mathrm{O}$ $(217 \mathrm{mg}), \mathrm{Mn}\left(\mathrm{CH}_{3} \mathrm{COO}\right)_{2} \cdot 4 \mathrm{H}_{2} \mathrm{O}, \mathrm{Co}\left(\mathrm{CH}_{3} \mathrm{COO}\right)_{2}$. $4 \mathrm{H}_{2} \mathrm{O} \quad(249 \mathrm{mg}), \quad \mathrm{Ni}\left(\mathrm{CH}_{3} \mathrm{COO}\right)_{2} \cdot 4 \mathrm{H}_{2} \mathrm{O} \quad(249$ $\mathrm{mg}), \quad \mathrm{Cu}\left(\mathrm{CH}_{3} \mathrm{COO}\right)_{2} \cdot \mathrm{H}_{2} \mathrm{O} \quad(199 \mathrm{mg}), \quad$ (245 $\mathrm{mg}), \quad \mathrm{Zn}\left(\mathrm{CH}_{3} \mathrm{COO}\right)_{2} .2 \mathrm{H}_{2} \mathrm{O} \quad(219 \mathrm{mg}), \quad$ and $\mathrm{Cd}\left(\mathrm{CH}_{3} \mathrm{COO}\right)_{2} \cdot 2 \mathrm{H}_{2} \mathrm{O}(267 \mathrm{mg})$ to a hot ethanolic solution $\left(50 \mathrm{~mL}, 60{ }^{\circ} \mathrm{C}\right)$ of the ligand $(459 \mathrm{mg}$ $1 \mathrm{mmol})$. The reaction mixtures were refluxed for $4 \mathrm{~h}$ accompanied by stirring. The precipitates which formed were filtered off, washed with ethanol then by diethyl ether and dried in vacuum desiccators over $\mathrm{P}_{4} \mathrm{O}_{10}$.

Complex (2): Yield (346 mg, 54\%), m.p. $>300{ }^{\circ} \mathrm{C}$; color: green; molar conductivity $\left({ }_{\mathrm{m}}\right)$ : $29.30 \mathrm{ohm}^{-1} \mathrm{~cm}^{2} \mathrm{~mol}^{-1}, \mu_{\text {eff }}$ (Magnetic susceptibility value): 1.66 BM. Elemental analysis for [VO(L) $\left(\mathrm{SO}_{4}\left(\mathrm{H}_{2} \mathrm{O}\right)\right], \quad \mathrm{C}_{25} \mathrm{H}_{23} \mathrm{~N}_{3} \mathrm{O}_{12} \mathrm{SV}, \quad(640.47)$ : Found (calcd.) \%C 45.90(46.88), \%H 3.50(3.62), \%N 6.70(6.56), \%S 4.23(5.01). IR ( $\left.\mathrm{KBr}, \mathrm{cm}^{-1}\right), 3426$, $v\left(\mathrm{H}_{2} \mathrm{O}\right), 1667,1629 v(\mathrm{C}=\mathrm{O}), 1570 v(\mathrm{C}=\mathrm{N}), 549$ $v(\mathrm{~V} \leftarrow \mathrm{O}), 476 v(\mathrm{~V} \leftarrow \mathrm{N}), 954 v(\mathrm{~V}=\mathrm{O}), 1141,1063$, $710 v\left(\mathrm{SO}_{4}^{2-}\right)$. UV. vis. (1 cm quartz cells, DMF) 260, 295, 340, 395, 425, 510, 590, $870 \mathrm{~nm}$.

Complex (3): Yield (453 mg, 64.3\%), m.p. $>300{ }^{\circ} \mathrm{C}$; color: brown; molar conductivity $\left({ }_{\mathrm{m}}\right)$ : $8.99 \mathrm{ohm}^{-1} \mathrm{~cm}^{2} \mathrm{~mol}^{-1}$, $\mu \mathrm{ef}=6.05 \mathrm{BM}$. Elemental analysis for $\left[\mathrm{Mn}(\mathrm{L})\left(\mathrm{CH}_{3} \mathrm{COO}\right)_{2}\left(\mathrm{H}_{2} \mathrm{O}\right)\right] \cdot 3 \mathrm{H}_{2} \mathrm{O}$, $\mathrm{C}_{29} \mathrm{H}_{35} \mathrm{~N}_{3} \mathrm{O}_{14} \mathrm{Mn}$, (704.54): Found (calcd) \% 49.56(49.44), \% 4.04(4.32), \% $6.31(5.96)$. IR $\left(\mathrm{KBr}, \mathrm{cm}^{-1}\right), 3412, v\left(\mathrm{H}_{2} \mathrm{O}\right), 1665,1617 v(\mathrm{C}=\mathrm{O})$, $1594 v(\mathrm{C}=\mathrm{N}), 589 v(\mathrm{Mn} \leftarrow \mathrm{O}), 511 v(\mathrm{Mn} \leftarrow \mathrm{N}), v_{\mathrm{s}}$ $\mathrm{CH}_{3} \mathrm{COO}, v_{\text {as }} \mathrm{CH}_{3} \mathrm{COO} 1571,1370\left(\Delta=201 \mathrm{~cm}^{-1}\right)$, UV. vis. ( $1 \mathrm{~cm}$ quartz cells, DMF) 255, 290, 350, $395,415,465,510,605 \mathrm{~nm}$.

Complex (4): Yield (400mg, 54.9\%), m.p. $>300$ ${ }^{\circ} \mathrm{C}$; color: Reddish brown, molar conductivity $\left({ }_{\mathrm{m}}\right)$ : $13.98 \mathrm{ohm}^{-1} \mathrm{~cm}^{2} \mathrm{~mol}^{-1} \mu \mathrm{eff}=4.33 \mathrm{BM}$. Elemental analysis for $\left[\mathrm{Co}(\mathrm{L})\left(\mathrm{CH}_{3} \mathrm{COO}\right)_{2}\left(\mathrm{H}_{2} \mathrm{O}\right)\right] \cdot 4 \mathrm{H}_{2} \mathrm{O}$, $\mathrm{C}_{29} \mathrm{H}_{37} \mathrm{~N}_{3} \mathrm{O}_{15} \mathrm{Co}$, (726.55): Found (calcd) \%C 47.39(47.94), \% $\mathrm{H}$ 4.50(5.13), \% $\mathrm{N} 6.51(5.78)$. IR $\left(\mathrm{KBr}, \mathrm{cm}^{-1}\right), 3423, v\left(\mathrm{H}_{2} \mathrm{O}\right), 1660,1627$ $v(\mathrm{C}=\mathrm{O}), 1612 v(\mathrm{C}=\mathrm{N}), 587 v(\mathrm{CoO}), 465 v(\mathrm{CoN})$, $v_{\mathrm{s}} \mathrm{CH}_{3} \mathrm{COO}, v_{\mathrm{as}} \mathrm{CH}_{3} \mathrm{COO} 1579,1349\left(\Delta=230 \mathrm{~cm}^{-}\right.$ 
1), UV. vis. (1 cm quartz cells, DMF) 260, 295, $365,420,510,615,925 \mathrm{~nm}$.

Complex (5): Yield (395 mg, 55.8\%), m.p. $>300^{\circ} \mathrm{C}$; color: green; molar conductivity $\left({ }_{\mathrm{m}}\right)$ : $9.78 \mathrm{ohm}^{-1} \mathrm{~cm}^{2} \mathrm{~mol}^{-1}$, eff $=3.05 \mathrm{BM}$. Elemental analysis for $\left[\mathrm{Ni}(\mathrm{L})\left(\mathrm{CH}_{3} \mathrm{COO}\right)_{2}\left(\mathrm{H}_{2} \mathrm{O}\right)\right] \cdot 3 \mathrm{H}_{2} \mathrm{O}$, $\mathrm{C}_{29} \mathrm{H}_{35} \mathrm{~N}_{3} \mathrm{O}_{14} \mathrm{Ni}$, (708.29): Found (calcd.) $\% \mathrm{C}$ $49.56(49.18), \% \mathrm{H}$ 4.56(4.98), $\% \mathrm{~N}$ 6.70(5.93). IR $\left(\mathrm{KBr}, \mathrm{cm}^{-1}\right), 3416, \quad v\left(\mathrm{H}_{2} \mathrm{O}\right), 1658,1627$ $v(\mathrm{C}=\mathrm{O}), 1580 v(\mathrm{C}=\mathrm{N}), 584 v(\mathrm{NiO}), 483 v(\mathrm{NiN})$, $v_{\mathrm{s}} \mathrm{CH}_{3} \mathrm{COO}, v_{\mathrm{ac}} \mathrm{CH}_{3} \mathrm{COO} 1563,1344\left(\Delta=219 \mathrm{~cm}^{-}\right.$ $\left.{ }^{1}\right)$, UV-vis. (1 $\mathrm{cm}$ quartz cells, DMF) 265, 280, $350,415,455,495,635,905 \mathrm{~nm}$.

Complex (6): Yield (412 mg, 57.8\%), m.p. $>300{ }^{\circ} \mathrm{C}$; color: olive; molar conductivity ${ }_{\mathrm{m}}$ ): $11.34 \mathrm{ohm}^{-1} \mathrm{~cm}^{2} \mathrm{~mol}^{-1}$, $\mu$ eff $=1.79 \mathrm{BM}$. Elemental analysis for $\left[\mathrm{Cu}(\mathrm{L})\left(\mathrm{CH}_{3} \mathrm{COO}\right)_{2}\left(\mathrm{H}_{2} \mathrm{O}\right)\right] \cdot 3 \mathrm{H}_{2} \mathrm{O}$, $\mathrm{C}_{29} \mathrm{H}_{35} \mathrm{~N}_{3} \mathrm{O}_{14} \mathrm{Cu}$, (713.15): Found (calcd) $\% \mathrm{C}$ 48.73(48.84), \% $4.39(4.95), \% \mathrm{~N}$ 6.53(5.89). IR $\left(\mathrm{KBr}, \mathrm{cm}^{-1}\right), 3421, v\left(\mathrm{H}_{2} \mathrm{O}\right), 1655,1629 v(\mathrm{C}=\mathrm{O})$, $1606 v(\mathrm{C}=\mathrm{N}), 583 \quad v(\mathrm{CuO}), 496 \quad v(\mathrm{CuN}), v_{\mathrm{s}}$ $\mathrm{CH}_{3} \mathrm{COO}, v_{2 \mathrm{cH}} \mathrm{COO} 1579,1353\left(\Delta=226 \mathrm{~cm}^{-1}\right)^{\mathrm{s}}$, UV-vis. (1 cm quartz cells, DMF) 255, 285, 340 , $405,440,705 \mathrm{~nm}$.

Complex (7): Yield (412 mg, 57.8\%), m.p. $>300{ }^{\circ} \mathrm{C}$; color: Yellow; molar conductivity $\left({ }_{\mathrm{m}}\right.$ ): $5.78 \mathrm{ohm}^{-1} \mathrm{~cm}^{2} \mathrm{~mol}^{-1}$, Elemental analysis for $[\mathrm{Zn}(\mathrm{L})$ $\left.\left(\mathrm{CH}_{3} \mathrm{COO}\right)_{2}\right], \mathrm{C}_{29} \mathrm{H}_{27} \mathrm{~N}_{3} \mathrm{O}_{10} \mathrm{Zn},(642.92)$ : Found (calcd) \%C $48.73(46.88), \% \mathrm{H} 4.39(3.62), \% \mathrm{~N}$ 6.53 (6.56). IR ( $\left.\mathrm{KBr}, \mathrm{cm}^{-1}\right), 3421, v\left(\mathrm{H}_{2} \mathrm{O}\right), 1655$, $1629 v(\mathrm{C}=\mathrm{O}), 1606 v(\mathrm{C}=\mathrm{N}), 583 v(\mathrm{Cu} \mathrm{O}), 496$ $v(\mathrm{Cu} \leftarrow \mathrm{N}), v_{\mathrm{s}} \mathrm{CH}_{3} \mathrm{COO}, v_{\mathrm{as}} \mathrm{CH}_{3} \mathrm{COO} 1579,1353$ $\left(\mathrm{D}=226 \mathrm{~cm}^{-1}\right)$, UV. vis. $(1 \mathrm{~cm}$ quartz cells, DMF) $270,285,355,410,445 \mathrm{~nm}$.

Complex (8): Yield (412 mg, 57.8\%), m.p. $>300{ }^{\circ} \mathrm{C}$; color: Dark Yellow; molar conductivity $\left({ }_{\mathrm{m}}\right): 18.67 \mathrm{ohm}^{-1} \mathrm{~cm}^{2} \mathrm{~mol}^{-1}$, Elemental analysis for $\left[\mathrm{Cd}(\mathrm{L})\left(\mathrm{CH}_{3} \mathrm{COO}\right)_{2}\left(\mathrm{H}_{2} \mathrm{O}\right)\right] \cdot 3 \mathrm{H}_{2} \mathrm{O}, \mathrm{C}_{29} \mathrm{H}_{35} \mathrm{~N}_{3} \mathrm{O}_{14} \mathrm{Cd}$, (762.01): Found (calcd) $\% \mathrm{C} 48.73(46.88), \% \mathrm{H}$ 4.39 (3.62), \%N 6.53 (6.56). IR ( $\left.\mathrm{KBr}, \mathrm{cm}^{-1}\right)$, $3421, v\left(\mathrm{H}_{2} \mathrm{O}\right), 1655,1629 v(\mathrm{C}=\mathrm{O}), 1606 v(\mathrm{C}=\mathrm{N})$, $583 v(\mathrm{Cd} \leftarrow \mathrm{O}), 496 \mathrm{v}(\mathrm{Cd} \leftarrow \mathrm{N}), v_{\mathrm{s}} \mathrm{CH}_{3} \mathrm{COO}, v_{\text {as }}$ $\mathrm{CH}_{3} \mathrm{COO} 1579,1353\left(\mathrm{D}=226 \mathrm{~cm}^{-1}\right)$, UV- vis. $(1$ cm quartz cells, DMF) 275, 295, 365, 435, 470 $\mathrm{nm}$.

\footnotetext{
Biological activity

Antimicrobial activity

Antimicrobial activities of the synthesized compounds (1-8) were evaluated against a panel of microorganisms in comparison with control drug chloramphenicol and metal salt solution.
}

Microorganisms used were Gram positive bacteria (Bacillus subtilis and Staphylococcus aureus), Gram-negative bacteria (Escherichia coli and Alcaligenes faecalis) and fungi (Candida albicans and Aspergillus niger). All microorganisms used were obtained from the culture collection of the Department of Chemistry of Natural and Microbial Products, National Research Center, Cairo, Egypt. The microorganisms were passaged at least twice to ensure purity and viability. The compounds were mounted on a concentration of $100 \mu \mathrm{g} / \mathrm{disc}$. The bacteria were maintained on nutrient agar medium while yeast and fungi were maintained on potato dextrose agar medium. DMSO showed no inhibition zone was used as a negative control. The agar media were incubated with different microorganism cultures tested. After $24 \mathrm{~h}$ of incubation at $30^{\circ} \mathrm{C}$ for bacteria and yeast and $72 \mathrm{~h}$ of incubation at $28^{\circ} \mathrm{C}$ for fungi, the diameter of inhibition zone in $\mathrm{mm}$ was measured. Chloramphenicol was used as a positive control for antimicrobial activity at concentration of 100 $\mu \mathrm{g} / \mathrm{disc}$.

\section{Preparation of the discs}

Compounds (1-8) together with the positive control (Chloramphenicol) were mounted on a paper disc prepared from blotting paper $(5 \mathrm{~mm}$ diameter) with the help of a micropipette in a concentration of $100 \mu \mathrm{g} / \mathrm{disc}$. The discs were applied on the microorganism-grown agar plates.

\section{Preparation of agar plates}

Minimal agar was used for the growth of specific microbial species. The preparation of agar plates for Bacillus subtilis, Staphylococcus aureus, Pseudomonas aeruginosa and Escherichia coli (bacteria) utilized nutrient agar $(2.30 \mathrm{~g} / 100 \mathrm{ml}$ distilled water; obtained from Panreac Quimica SA, Spain), and potato dextrose agar medium $(3.9 \mathrm{~g} / 100 \mathrm{ml}$ distilled water; obtained from Merck) for Candida albicans and Aspergillus niger (fungi). This was allowed to soak for 15 min and then boiled on a water bath until the agar was completely dissolved. The mixture was autoclaved for $15 \mathrm{~min}$ at $120^{\circ} \mathrm{C}$ and then poured into previously sterilized Petri dishes and stored at $30{ }^{\circ} \mathrm{C}$ for inoculation.

Inoculation procedure: Spore suspension was prepared with the help of a platinum wire loop to reach a microbial concentration equivalent 0.5 Mac-Farland.

Application of the discs: Sterilized forceps were used for the application of the paper disc on 
previously inoculated agar plates. When the discs were applied, they were incubated at $37^{\circ} \mathrm{C}$ for 24 $\mathrm{h}$ for bacteria and yeast, and at $28{ }^{\circ} \mathrm{C}$ for $48 \mathrm{~h}$ for fungi. The zone of inhibition around the disc was then measured in millimeters.

\section{$\underline{\text { Results and Discussion }}$}

\section{Chemistry}

A new Schiff base ligand was prepared from condensation of 4-aminoantipyrine and Furobenzopyrone. The furochromone Schiff base forms 1:1 complexes with $\mathrm{VO}^{\mathrm{II}}, \mathrm{Ni}^{\mathrm{II}}, \mathrm{Cu}^{\mathrm{II}}$, $\mathrm{Co}^{\mathrm{II}}, \mathrm{Mn}^{\mathrm{II}}, \mathrm{Cd}^{\mathrm{II}}$ and $\mathrm{Zn}^{\mathrm{II}}$ salts. The elemental analysis and spectroscopic studies of the newly synthesized compounds (1-8) are consistent with the proposed structures (Fig.1-3). All the obtained metal complexes are colored, non-hygroscopic, air-stable and insoluble in water, but they demonstrated a good solubility character in DMF and DMSO.

\section{Infrared spectra}

IR spectral data of the prepared compounds (1-8) are given in experimental part. The ligand IR spectrum showed peaks at 1680, 1652 and $1625 \mathrm{~cm}^{-1}$, that due to the two carbonyl groups of antipyrine moiety, Furobenzopyrone moiety and azomethine group respectively.[23, 32, 33] The comparison of the IR spectra of the ligand and its complexes showed that, the ligand works as a neutral tridentate ligand coordinating to the metal ions through the carbonyl oxygen atoms of furobezopyrone, antipyrine moieties and azomethine nitrogen atom. This coordination can be demonstrated through the following observations i) the lower frequency shift in bands characteristic to the two carbonyl and azomethine groups of ligand.[32] ii) The existence of new bands in the 565-594 and 465-511 $\mathrm{cm}^{-1}$ ranges could be due to the $v(\mathrm{M} \leftarrow \mathrm{O})$, and $v(\mathrm{M} \leftarrow \mathrm{N})$ respectively. [32] iii) the appearance of two characteristic peaks in the 1555-1579 $\mathrm{cm}^{-1}$ and $1344-1370 \mathrm{~cm}^{-1}$ ranges were attributed to $v_{\mathrm{as}}\left(\mathrm{COO}^{-}\right)$and $v_{\mathrm{s}}\left(\mathrm{COO}^{-}\right)$, respectively, indicating the involvement of the carboxylate oxygen in the chelation as monodentate ligand.[33] iv) the presence of new bands appeared at 1141, 1063, $710 \mathrm{~cm}^{-1}$ in the IR spectrum of complex (2). These bands indicate that the sulphate group is coordinated to the $\mathrm{VO}^{\mathrm{II}}$ ion as chelating unidentate fashion. Also, it exhibits a peak at $954 \mathrm{~cm}^{-1}$ that, could be imputed to $\mathrm{n}(\mathrm{V}=\mathrm{O})[34]$

Nuclear magnetic resonance spectrum

The ligand ${ }^{1} \mathrm{H}-\mathrm{NMR}$ spectrum in DMSO- $\mathrm{d}_{6}$ is in agreement with the proposing structure (Fig. 1). The singlet at $8.79 \mathrm{ppm}$ was ascribed to the azomethine proton $\left(\mathrm{s}, 1 \mathrm{H}, \mathrm{N}={ }^{1} \mathrm{CH}\right)$. [35] Whereas the chemical shifts observed as singlet at $7.85(\mathrm{~s}$, $\left.1 \mathrm{H},{ }^{22} \mathrm{CH}\right)$ as well as the doublet at $7.50(\mathrm{~d}, 1 \mathrm{H}$,

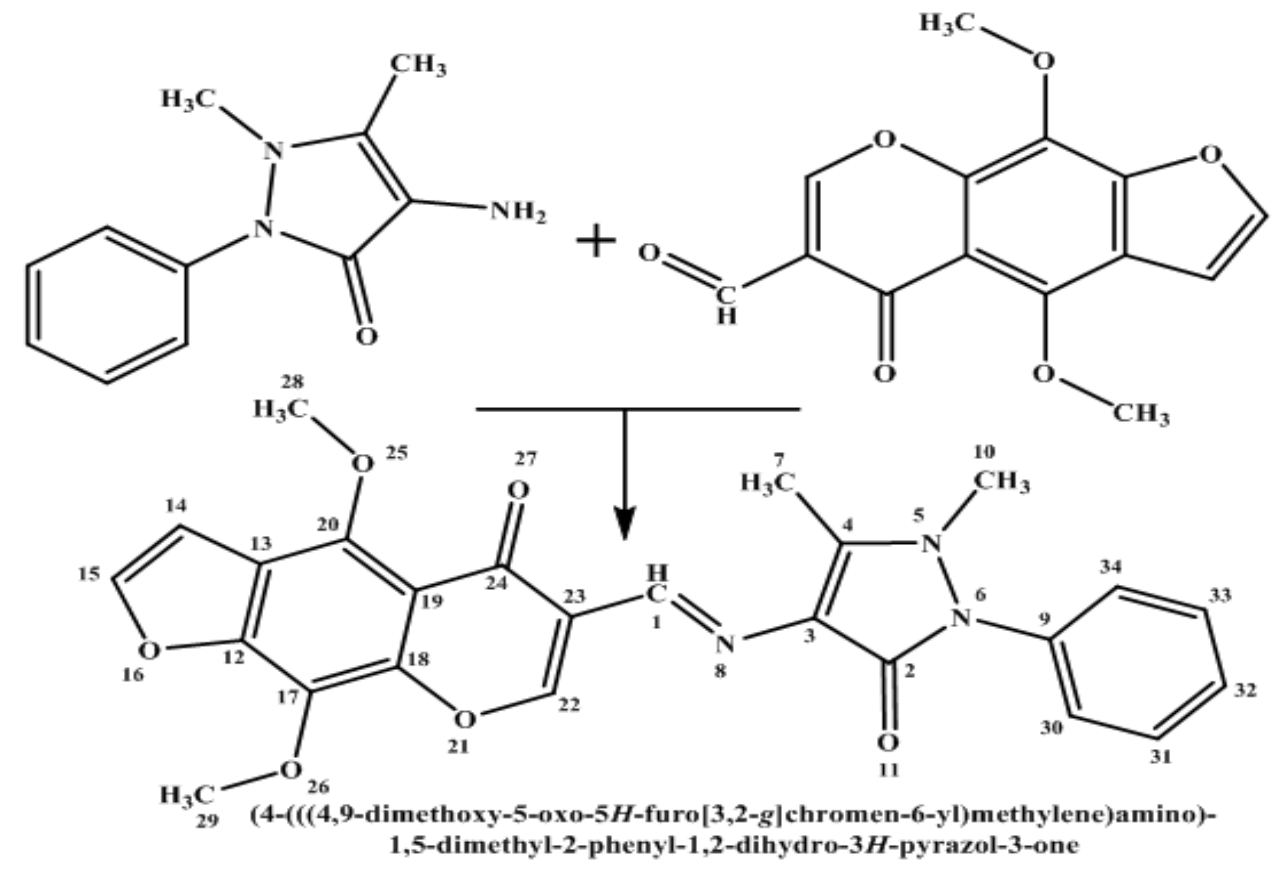

Fig.1: Synthesis of furochromone Schiff base ligand. 


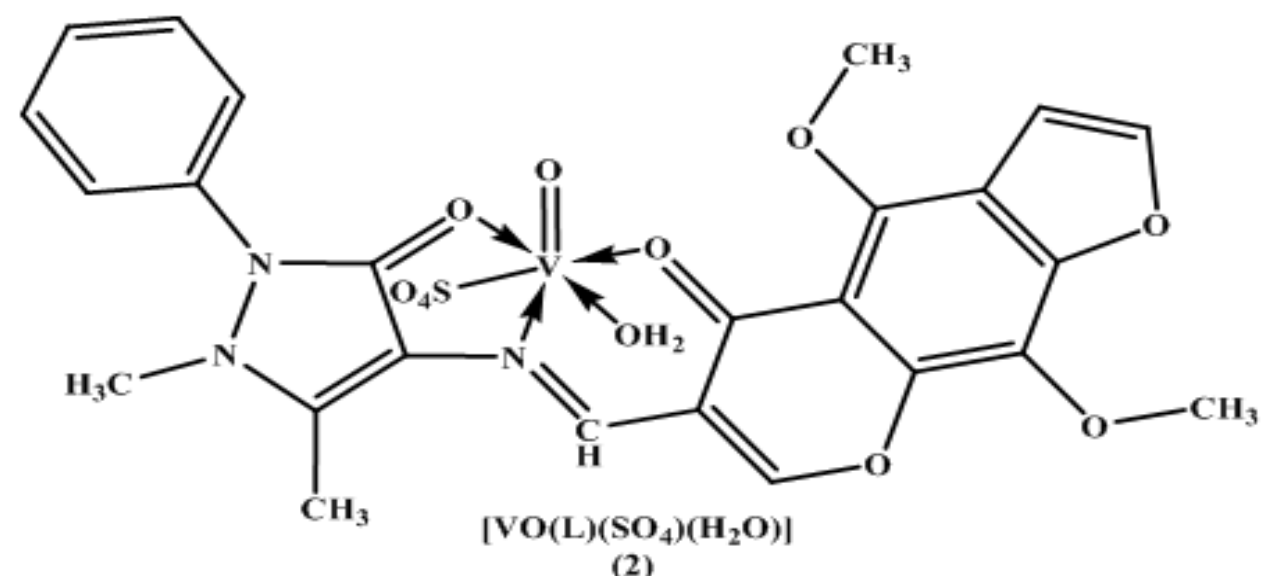

Fig. 2: Proposed structure for vanadyl complex (2).

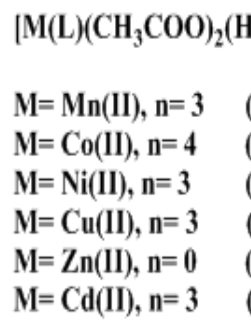

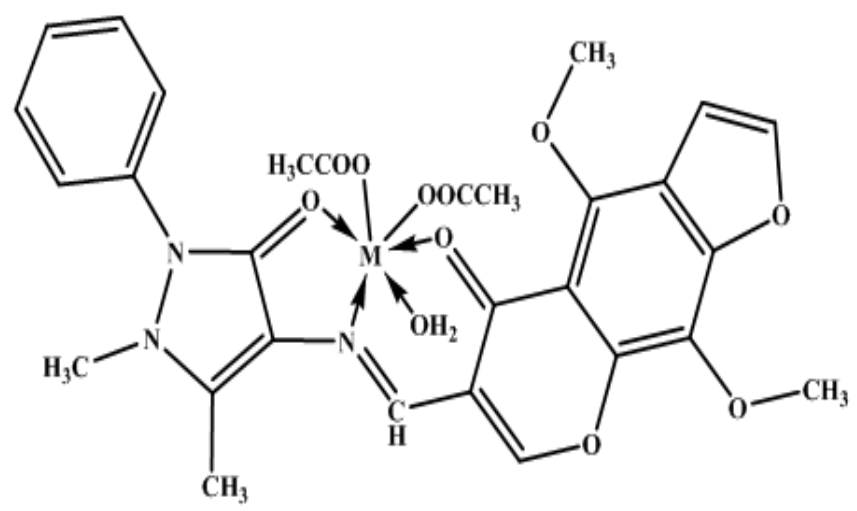

Fig. 3: Proposed structure for metal complexes (3-8).

$\left.{ }^{15} \mathrm{CH}\right)$ and $7.07\left(\mathrm{~d}, 1 \mathrm{H},{ }^{14} \mathrm{CH}\right)$ could be ascribed to the protons of khellin moiety.[3] The protons of the methoxy groups of khellin moiety were observed as singlet at 4.10 and $3.97 \mathrm{ppm} .[3]$ The aromatic protons of antipyrine moiety appeared in the 7.30-7.47 ppm.[23-26] While the singlet appeared at $2.42 \mathrm{ppm}\left(\mathrm{s}, 3 \mathrm{H}, \mathrm{N}-{ }^{10} \mathrm{CH}_{3}\right)$ and 3.14 ppm (s, $\left.3 \mathrm{H}, \mathrm{C}_{-}{ }^{7} \mathrm{CH}_{3}\right)$ attributed to the protons of antipyrine moiety methyl groups.[23-26]

\section{Molar-conductance measurements}

The molar conductivity measurements for the complexes (2-8) are carried out in DMF at concentration $10^{-3} \mathrm{M}$ and given in experimental part. The molar conductivity values fall in the range $5.78-29.30 \mathrm{ohm}^{-1} \mathrm{~cm}^{2} \mathrm{~mol}^{-1}$ which is confirmed that complexes (2-8) are nonelectrolytes.[36] These values also support the participation of the acetate and sulfate groups in coordination.

Electronic absorption spectra and magnetic susceptibility measurements

The electronic spectral data of the compounds in DMSO as well as magnetic moment data for solid complexes are illustrated in experimental part. The ligand spectrum displayed four peaks at $255,295,330$ and $385 \mathrm{~nm}$, the first two peaks ascribed to the $\pi \rightarrow \mathrm{p}^{*}$ transition within the benzoniod and Furobenzopyrone moieties.[37] Whereas the other two peaks imputed to $n \rightarrow p^{*}$ of the imine and carbonyl groups.[38] The last two peaks showed a bathochromic shift denoting that the imine nitrogen and carbonyl oxygen atoms are involved in coordination to the metal ion.[39] The $\mathrm{VO}^{2+}$ complex (2) exhibited magnetic moment value equal $1.66 \mathrm{BM}$ and three absorption bands at $870,590,510 \mathrm{~nm}$, for $\left\{{ }^{2} \mathrm{~B}_{2}\left(\mathrm{~d}_{\mathrm{xy}}\right){ }^{\circledR} \mathrm{E}_{1}\left(\mathrm{~d}_{\mathrm{xz}}, \mathrm{d}_{\mathrm{zy}}\right)\right.$ $\left(v_{1}\right),{ }^{2} \mathrm{~B}_{2}\left(\mathrm{~d}_{\mathrm{xy}}\right) \rightarrow{ }^{2} \mathrm{~B}_{1}\left(\mathrm{~d}_{\mathrm{xz}-\mathrm{y} 2}\right)\left(v_{2}\right), \quad{ }^{2} \mathrm{~B}_{2}\left(\mathrm{~d}_{\mathrm{xy}}\right) \rightarrow{ }^{2} \mathrm{~A}_{1}\left(\mathrm{~d}_{\mathrm{zz} 2}\right)$ $\left.\left(v_{3}\right)\right\}$ transitions respectively.[26] These results correspond to distorted octahedral geometry. ${ }^{[40}$, 41] $\mathrm{The} \mathrm{Mn}^{2+}$ complex (3) electronic absorption spectrum displayed weak absorption peaks at 605 , $510,465 \mathrm{~nm}$ assignable to $\left\{{ }^{6} \mathrm{~A}_{1 \mathrm{~g}} \rightarrow{ }^{4} \mathrm{~T}_{1 \mathrm{~g}}(4 \mathrm{G})\left(v_{1}\right)\right.$, $\left.{ }^{6} \mathrm{~A}_{1 \mathrm{~g}} \rightarrow{ }^{4} \mathrm{E}_{\mathrm{g}}(4 \mathrm{G})\left(v_{2}\right),{ }^{6} \mathrm{~A}_{1 \mathrm{~g}} \rightarrow{ }^{4} \mathrm{E}_{\mathrm{g}}(4 \mathrm{D})\left(v_{3}\right)\right\}$ transitions respectively, which are well-matched with the octahedral geometry.[40, 42] The magnetic moment value of this complex equals $6.05 \mathrm{BM}$, 
inductive to five unpaired electrons system and close to high spin $\mathrm{Mn}^{2+}\left(\mathrm{d}^{5}\right) \cdot \mathrm{Co}^{2+}$ complex (4) spectrum showed peaks at 925, 615 and 510 for $\quad\left\{{ }^{4} \mathrm{~T}_{\mathrm{lg}}(\mathrm{F}) \rightarrow{ }^{4} \mathrm{~T}_{2} \mathrm{~g}(\mathrm{~F})\left(v_{1}\right), \quad{ }^{4} \mathrm{~T}_{\mathrm{lg}}(\mathrm{F}) \rightarrow{ }^{4} \mathrm{~A}_{2 \mathrm{~g}}(\mathrm{~F})\left(v_{2}\right)\right.$, $\left.{ }^{4} \mathrm{~T}_{1 \mathrm{~g}}(\mathrm{~F}) \rightarrow{ }^{4} \mathrm{~T}_{2 \mathrm{~g}}(\mathrm{P})\left(v_{3}\right)\right\} \quad$ transitions respectively, which referring that the ligands arranged around the cobalt(II) in an octahedral geometry.[40, 43] The magnetic moment value of cobalt complex is $3.88 \mathrm{BM}$, which Inductive to three unpaired electrons and close to a high spin $\mathrm{Co}^{2+}\left(\mathrm{d}^{7}\right)$. The $\mathrm{Ni}^{2+}$ complex (5) displayed a magnetic moment value at 3.05 BM and three absorption peaks at 905 , 605 and $495 \mathrm{~nm}$ inductive to $\left\{{ }^{3} \mathrm{~A}_{2 \mathrm{~g}}(\mathrm{~F}) \rightarrow{ }^{3} \mathrm{~T}_{2 \mathrm{~g}}(\mathrm{~F})\right.$

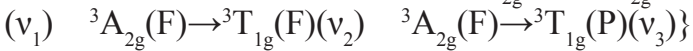
transitions respectively.[40, 43] These data supported the distorted octahedral geometry for $\mathrm{Ni}^{2+}$ complex.[43] The $\mathrm{Cu}^{2+}$ complex (6) showed magnetic moment value at $1.79 \mathrm{BM}$ and only one broad band at $705 \mathrm{~nm}$, which could be imputed to superimposed transitions $\left\{{ }^{2} \mathrm{~B}_{1 \mathrm{~g}}\left(\mathrm{~d}_{\mathrm{x} 2-\mathrm{y} 2}\right) \rightarrow{ }^{2} \mathrm{~A}_{1 \mathrm{~g}} \mathrm{~d}_{\mathrm{z} 2(v 1)}\right.$, ${ }^{2} \mathrm{~B}_{1 \mathrm{~g}}\left(\mathrm{~d}_{\mathrm{x} 2-\mathrm{y} 2}\right) \rightarrow{ }^{2} \mathrm{~B}_{2 \mathrm{~g}}\left(\mathrm{~d}_{\mathrm{xy}}\right){ }_{(\mathrm{y} 2)},{ }^{2} \mathrm{~B}_{1 \mathrm{~g}}\left(\mathrm{~d}_{\mathrm{x} 2-\mathrm{y} 2}\right) \rightarrow{ }^{2} \mathrm{E}_{\mathrm{g}}\left(\mathrm{d}_{\mathrm{zy},} \mathrm{d}_{\mathrm{xz}}\right)$ $\left.{ }_{\left({ }_{3}\right)}\right\}$. These data referring that this $\mathrm{Cu}^{2+}$ complex (6) has a distorted octahedral molecular geometry. $[25,40]$ The diamagnetic $\mathrm{Zn}^{2+}$ and $\mathrm{Cd}^{2+}$ complexes (7) and (8) have $d^{10}$ system, so it does not show d-d transitions. The peaks which observed could be owing to intra-ligand transitions.[44]

\section{Thermal analysis of complexes}

The water molecules nature in the complexes (2-8) was elucidated by measuring the TG analysis in the $20-800{ }^{\circ} \mathrm{C}$ range. The thermal manner of complexes (2-8) displayed that the calculated weight loss is agreeable with the found calculated weight loss. The TG data (Table 1) displayed that, the complexes (3-6) and (8) decomposed in four successive steps. The first step carried out in the $60-110{ }^{\circ} \mathrm{C}$ range with found weight loss ranged between 6.77 and 9.12 $\%$ (calcd. 7.09-9.92\%) owing to the departure of water molecules of hydration. The second step procured between $110-190{ }^{\circ} \mathrm{C}$ with found weight loss 2.32 - $2.66 \%$ (calcd. 2.36-2.56\%) due to departure of coordination water molecules. The third step occurred in the $180-260{ }^{\circ} \mathrm{C}$ range with found weight loss ranged between 14.87and $16.50 \%$ (calcd. 15.60-16.87\%) which imputed to the acetate ions removal $\left(2 \mathrm{CH}_{3} \mathrm{COOH}\right)$. The last step which represent the whole degeneration was occurred in the range $390-600{ }^{\circ} \mathrm{C}$ with found weight lack ranged between 55.87-60.57\% (calcd. 58.09-62.83\%) ending with formation of metal oxides $\mathrm{MnO}, \mathrm{CoO}, \mathrm{NiO}, \mathrm{CuO}$ and $\mathrm{CdO}$ consecutively. Complexes (2) and (7) degraded in three successive stages. The first stage take place in the $125-175^{\circ} \mathrm{C}$ with $2.55,2.58 \%$ weight loss (calcd. 2.81 and $2.80 \%$ ) due to departure of the coordination water molecules. The next step in the $135-190{ }^{\circ} \mathrm{C}$ with 14.33 and $17.66 \%$ weight loss (calcd. 15.00, 18.49\%) which imputed to the removal the sulfate and acetate ions $\left(2 \mathrm{CH}_{3} \mathrm{COOH}\right)$ for two complexes consecutively. The last step which represents the whole degeneration occurred in the $390-545{ }^{\circ} \mathrm{C}$ with found weight loss equal to 65.66 and $65.28 \%$ (calcd. 68.79 and $66.05 \%$ ) ending with formation of metal oxides $\mathrm{V}_{2} \mathrm{O}_{5}$ and $\mathrm{ZnO}$ consecutively.

\section{Biological activity study}

All compounds (1-8) were subjected to antibacterial and antifungal screening tests against panel of microorganisms as Bacillus subtilis, Staphylococcus aureus, Escherichia coli, Alcaligenes faecalis, Candida albicans, Aspergillus niger. The screening data in Table 2 revealed that; the ligand (1) exhibits weak antifungal activity and does not show antibacterial activity while metal salts solution exhibits week antifungal and antibacterial activities. The Metal complexes (2-8) exhibit antimicrobial activity ranged from moderate to strong compared with positive control (chloramphenicol). Among the tested compounds, complexes (6-7) reveal potent antimicrobial activity towards the tested species \{gram positive bacteria, gram negative bacteria, fungi\}. Whereas complexes (2-3, 8) show moderate antimicrobial activity, while complexes (4-5) display moderate antifungal activity with weak antibacterial activity (only against the $G$ +ve bacterium A. Faecalis). The antifungal and antibacterial activities of the ligand (1) can be enhanced through coordination with metal ions..$^{[45]}$ Where the chelation reduces the polarity of metal ions and increases their lipophilic nature, thus the penetration of these metal ions through the cell membrane of microorganism can be increased. [46] So that the chelating increase the bactericidal properties of the ligand, thus inhibiting the growth of microorganism.[46-49] Besides, the significant biological activity of complexes (2-8) may also due to the change in their dipole moment, solubility and conductivity.

\section{Conclusion}

In this study a new furochromone Schiff base was prepared from condensation of 4-aminoantipyrine and 4,9-dimethoxy furochromene-6-carbaldehyde. The furochromone Schiff base forms 1:1 complexes with $\mathrm{VO}^{\mathrm{II}}, \mathrm{Ni}^{\mathrm{II}}$, $\mathrm{Cu}^{\mathrm{II}}, \mathrm{Co}^{\mathrm{II}}, \mathrm{Mn}^{\mathrm{II}}, \mathrm{Cd}^{\mathrm{II}}$ and $\mathrm{Zn}^{\mathrm{II}}$ salts. The elemental 
TABLE 1. Thermal analyses for metal (II) complexes (2-8)

\begin{tabular}{|c|c|c|c|c|}
\hline No. & $\begin{array}{c}\text { Temp. } \\
\text { range }{ }^{\circ} \mathrm{C}\end{array}$ & $\begin{array}{l}\text { Loss in weight } \\
\text { Found (calcd.) }\end{array}$ & Assignment & $\begin{array}{l}\text { Composition } \\
\text { of the residue }\end{array}$ \\
\hline \multirow{3}{*}{ (2) } & $130-160$ & $2.55(2.81)$ & Removal of coordinated water molecule $\left(\mathrm{H}_{2} \mathrm{O}\right)$ & {$\left[\mathrm{VO}(\mathrm{L}) \mathrm{SO}_{4}\right]$} \\
\hline & $160-190$ & $14.33(15.00)$ & Removal of sulphate group $\left(\mathrm{SO}_{4}\right)$ & {$[\mathrm{VO}(\mathrm{L})]$} \\
\hline & $390-525$ & $65.66(68.79)$ & Complex decomposition forming $\mathrm{V}_{2} \mathrm{O}_{5}$ & {$\left[\left(\mathrm{~V}_{2} \mathrm{O}_{5}\right]\right.$} \\
\hline \multirow{4}{*}{ (3) } & $65-95$ & $7.78(7.67)$ & Dehydration process $\left(3 \mathrm{H}_{2} \mathrm{O}\right)$ & {$\left[\mathrm{Mn}(\mathrm{L})\left(\mathrm{CH}_{3} \mathrm{COO}\right)_{2}\left(\mathrm{H}_{2} \mathrm{O}\right)\right]$} \\
\hline & $110-180$ & $2.32(2.56)$ & Removal of coordinated water molecule $\left(\mathrm{H}_{2} \mathrm{O}\right)$ & {$\left[\mathrm{Mn}(\mathrm{L})\left(\mathrm{CH}_{3} \mathrm{COO}\right)_{2}\right]$} \\
\hline & $205-265$ & $16.50(16.87)$ & Removal of two acetate ions $\left(2 \mathrm{CH}_{3} \mathrm{COOH}\right)$ & {$[\mathrm{Mn}(\mathrm{L})]$} \\
\hline & $400-535$ & $60.28(62.83)$ & Complex decomposition forming $\mathrm{MnO}$ & $\mathrm{MnO}$ \\
\hline \multirow{4}{*}{ (4) } & $75-110$ & $9.12(9.92)$ & Dehydration process $\left(4 \mathrm{H}_{2} \mathrm{O}\right)$ & {$\left[\mathrm{Co}(\mathrm{L})\left(\mathrm{CH}_{3} \mathrm{COO}\right)_{2}\left(\mathrm{H}_{2} \mathrm{O}\right)\right]$} \\
\hline & $120-175$ & $2.59(2.48)$ & Removal of coordinated water molecule $\left(\mathrm{H}_{2} \mathrm{O}\right)$ & {$\left[\mathrm{Co}(\mathrm{L})\left(\mathrm{CH}_{3} \mathrm{COO}\right)_{2}\right]$} \\
\hline & $195-235$ & $15.55(16.36)$ & Removal of two acetate ions $\left(2 \mathrm{CH}_{3} \mathrm{COOH}\right)$ & {$[\mathrm{Co}(\mathrm{L})]$} \\
\hline & $450-600$ & $56.88(60.93)$ & Complex decomposition forming $\mathrm{CoO}$ & $\mathrm{CoO}$ \\
\hline \multirow{4}{*}{ (5) } & $70-100$ & $7.50(7.63)$ & Dehydration process $\left(3 \mathrm{H}_{2} \mathrm{O}\right)$ & {$\left[\mathrm{Ni}(\mathrm{L})\left(\mathrm{CH}_{3} \mathrm{COO}\right)_{2}\left(\mathrm{H}_{2} \mathrm{O}\right)\right]$} \\
\hline & $110-155$ & $2.33(2.54)$ & Removal of coordinated water molecule $\left(\mathrm{H}_{2} \mathrm{O}\right)$ & {$\left[\mathrm{Ni}(\mathrm{L})\left(\mathrm{CH}_{3} \mathrm{COO}\right)_{2}\right]$} \\
\hline & $200-240$ & $16.22(16.78)$ & Loss of two acetate ions $\left(2 \mathrm{CH}_{3} \mathrm{COOH}\right)$ & {$[\mathrm{Ni}(\mathrm{L})]$} \\
\hline & $430-520$ & $60.57(62.50)$ & Complex decomposition forming $\mathrm{NiO}$ & $\mathrm{NiO}$ \\
\hline \multirow{4}{*}{ (6) } & $65-105$ & $7.77(7.58)$ & Dehydration process $\left(3 \mathrm{H}_{2} \mathrm{O}\right)$ & {$\left[\mathrm{Cu}(\mathrm{L})\left(\mathrm{CH}_{3} \mathrm{COO}\right)_{2}\left(\mathrm{H}_{2} \mathrm{O}\right)\right]$} \\
\hline & $115-165$ & $2.49(2.53)$ & Removal of coordinated water molecule $\left(\mathrm{H}_{2} \mathrm{O}\right)$ & {$\left[\mathrm{Cu}(\mathrm{L})\left(\mathrm{CH}_{3} \mathrm{COO}\right)_{2}\right]$} \\
\hline & $180-245$ & $16.07(16.67)$ & Removal of two acetate ions $\left(2 \mathrm{CH}_{3} \mathrm{COOH}\right)$ & {$[\mathrm{Cu}(\mathrm{L})]$} \\
\hline & $400-555$ & $59.33(62.07)$ & Complex decomposition forming $\mathrm{CuO}$ & $\mathrm{CuO}$ \\
\hline \multirow{3}{*}{ (7) } & $125-175$ & $2.58(2.80)$ & Removal of coordinated water molecule $\left(\mathrm{H}_{2} \mathrm{O}\right)$ & {$\left[\mathrm{Zn}(\mathrm{L})\left(\mathrm{CH}_{3} \mathrm{COO}\right)_{2}\right]$} \\
\hline & $195-235$ & $17.66(18.49)$ & Removal of two acetate ion $\left(2 \mathrm{CH}_{3} \mathrm{COOH}\right)$ & {$[\mathrm{Zn}(\mathrm{L})]$} \\
\hline & $390-545$ & $65.28(66.05)$ & Complex decomposition forming $\mathrm{ZnO}$ & $\mathrm{ZnO}$ \\
\hline \multirow{4}{*}{ (8) } & $60-95$ & $6.77(7.09)$ & Dehydration process $\left(3 \mathrm{H}_{2} \mathrm{O}\right)$ & {$\left[\mathrm{Cd}(\mathrm{L})\left(\mathrm{CH}_{3} \mathrm{COO}\right)_{2}\left(\mathrm{H}_{2} \mathrm{O}\right)\right]$} \\
\hline & $135-190$ & $2.66(2.36)$ & Removal of coordinated water molecule $\left(\mathrm{H}_{2} \mathrm{O}\right)$ & {$\left[\mathrm{Cd}(\mathrm{L})\left(\mathrm{CH}_{3} \mathrm{COO}\right)_{2}\right]$} \\
\hline & $205-260$ & $14.87(15.60)$ & Removal of two acetate ions $\left(2 \mathrm{CH}_{3} \mathrm{COOH}\right)$ & {$[\mathrm{Cd}(\mathrm{L})]$} \\
\hline & $450-585$ & $55.67(58.09)$ & Complex decomposition forming $\mathrm{CdO}$ & $\mathrm{CdO}$ \\
\hline
\end{tabular}

TABLE 2. Antimicrobial activity of furochromone Schiff base compounds (1-8).

\begin{tabular}{|c|c|c|c|c|c|c|c|}
\hline & Organisms & Gram po & e bacteria & Gram neg & acteria & & \\
\hline No. & Compounds & E. coli & A. faecalis & S. aureus & B. subtilis & C. albicans & A. niger \\
\hline 1 & Ligand (L) & - & - & + & - & ++ & + \\
\hline 2 & $\mathrm{VO}^{\mathrm{II}}$ complex & & & & & & \\
\hline 3 & Mn ${ }^{\text {II }}$ complex & ++ & + & +++ & + & +++ & +++ \\
\hline 4 & $\mathrm{Co}^{\mathrm{II}}$ complex & ++ & ++ & + & + & ++ & ++ \\
\hline 5 & $\mathrm{Ni}^{\mathrm{II}}$ complex & + & + & - & + & +++ & ++ \\
\hline 6 & $\mathrm{Cu}^{\mathrm{II}}$ complex & +++ & ++ & +++ & ++ & ++++ & ++++ \\
\hline 7 & $\mathrm{Zn}^{\Pi}$ complex & +++ & ++++ & ++++ & ++++ & ++++ & ++++ \\
\hline 8 & $\mathrm{Cd}^{\mathrm{II}}$ complex & & & & & & \\
\hline (a) & Chloramphenicol & ++++ & ++++ & ++++ & ++++ & ++++ & +++ \\
\hline (b) & DMSO & - & - & - & - & - & - \\
\hline
\end{tabular}

Inhibition zone diameter (\% inhibition) : +6-9 mm (33-50\%); ++ 10-12 mm(55-67\%); +++13-15 mm (72-83\%); ++++ 16-18 $\mathrm{mm}(89-100 \%)$; a:standard drug (positive control)

b:solvent (negative control) 
analysis and spectroscopic studies of the newly synthesized compounds (1-8) showed that, the furochromone Schiff base acts as tridentate ligand. Where, it is coordinating with metal ions through the carbonyl oxygen atoms of furobezopyrone and antipyrine moieties and azomethine nitrogen atom. All prepared metal complexes showed a nonelectrolytes nature. The coordination geometries around the metal centers in these complexes are distorted octahedral geometry. The antimicrobial evaluation of all compounds revealed that the ligand exhibits weak antifungal activity, whereas the metal complexes exhibit antimicrobial activity ranged from moderate to strong. Nickel and Zinc complexes exhibit potent antimicrobial activity compared with other complexes and standard drug (chloramphenicol).

\section{References}

1. Khalfallah, A., Labed, A., Z. Semar, Z., AI Kaki, B., Kabouche, A., Touzani, R. and Kabouche, Z. Antibacterial activity and chemical composition of the essential oil of Ammi visnaga L. (Apiaceae) from Constantine, Algeria, Int. J. Med. Aromatic Plants, 1, 302 (2011).

2. El-Sawy, E. R., Mandour, A. H., Islam, I. E. and AboSalem, H. M. Synthesis and antimicrobial evaluation of some new 6-substituted furobenzopyrone derivatives, Egypt. J. Chem., 51, 523 (2008).

3. El-Sawy, E. R., Shaker, K. H., Mandour, A. H., Shehab El-Din, A. and Abdula, M. M. Synthesis and pharmacological activities of novel furobenzopyrone and benzofuran derivatives, Indian J. Chem. Sect. B Org. Med. Chem., 47, 1451 (2008).

4. Maleck, M., dos Santos, F. C. C., Serdeiro, M. T., Guimarães, A. É., Ferreira, B., Gunaydin, K. and de Almeida, A. P. Khellin: A furanochromone with toxicity against Oncopeltus fasciatus (Hemiptera) and Aedes aegypti (Diptera), J. Nat.Pharm., 4, 32 (2013)

5. Bencheraiet, R., Kherrab, H., Kabouche, A., Kabouche, Z. and Jay, M. Flavonols and Antioxidant Activity of Ammi visnaga L. (Apiaceae), Rec. Nat. Prod., 5, 52 (2011).

6. Abu-Hashem, A. A. and Youssef, M. M. Synthesis of new visnagen and khellin furochromone pyrimidine derivatives and their anti-inflammatory and analgesic activity, Molecules, 16, 1956 (2011).

7. El-Sawy, E. R., Ebaid, M. S., Abo-Salem, H. M., Al-Sehemi, A. G. and Mandour, A. H. Synthesis, anti-inflammatory, analgesic and anticonvulsant activities of some new 4,6-dimethoxy-5(heterocycles)benzofuran starting from naturally occurring visnagin, Arab. J. Chem., 7, 914 (2014).

8. Cordero, C. P., Gómez-González, S., León-Acosta, C. J., Morantes-Medina, S. J. and Aristizabal, F. A. Cytotoxic activity of five compounds isolated from Colombian plants, Fitoterapia, 75, 225 (2004).

9. Galal, S. A., Abd El-All, A. S., Hegab, K. H., Magd-El-Din, A. A., Youssef, N. S. and El-Diwani, H. I. Novel antiviral benzofuran-transition metal complexes, Eur. J. Med. Chem., 45, 3035 (2010).

10. Galal, S. A., Abd El-All, A. S., Abdallah, M. M. and El-Diwani, H. I. Synthesis of potent antitumor and antiviral benzofuran derivatives, Bioorg. Med. Chem. Lett., 19, 2420 (2009).

11. Abd El-All, A. S., Atta, S. M. S., Roaiah, H. M. F., Awad, E. M. and Abdalla, M. M. New Potent SARS-CoV 3C-Like Protease Inhibitors Derived from Thieno[2,3-d]-pyrimidine Derivatives, Arch. Pharm., 349, 202 (2016).

12. Kandil, A., Gobran, W., Samaan, H. A. and Abu Shady, H. The spasmolytic potential of a new khellin derivative, J. DRUG RES., 9, 35 (1977).

13. Whitton, M. E., Ashcroft, D. M. and González, U. Therapeutic interventions for vitiligo, J. Am. Acad. Dermatol., 59, 713 (2008).

14. De Leeuw, J., Assen, Y. J., Van Der Beek, N., Bjerring, P. and Martino Neumann, H. A. Treatment of vitiligo with khellin liposomes, ultraviolet light and blister roof transplantation, J. Eur. Acad. Dermatol. Venereol., 25, 74 (2011).

15. Vedaldi, D., Caffieri, S., Dell'Acqua, F., Andreassi, L., Bovalini, L. and Martelli, P. Khellin, a naturally occurring furochromone, used for the photochemotherapy of skin diseases: Mechanism of action, FARMACO ED. SCI., 43, 333 (1988).

16. Abdel-Fattah, A., Aboul-Enein, M. N., Wasset, G. M. and El-Menshawi, B. S. An approach to the treatment of vitiligo by khellin, Dermatology, 165, 136 (1982).

17. Abdel-Fattah, A., Aboul-Enein, N. M., Wassel, G. and El-Menshawi, B. Preliminary report on the therapeutic effect of khellin in psoriasis, Dermatology, 167, 109 (1983).

18. Kwon, M. S., Lee, J. K., Park, S. H., Sim, Y. B., Jung, J. S., Won, M. H., Kim, S. M. and Suh, H. W. Neuroprotective effect of visnagin on kainic acid-induced neuronal cell death in the mice

Egypt. J. Chem. 61, No.2 (2018) 
hippocampus, Korean J. Physiol. Pharmacol., 14, 257 (2010).

19. Lee, J. K., Jung, J. S., Park, S. H., Park, S. H., Sim, Y. B., Kim, S. M., Ha, T. S. and Suh, H. W. Anti-inflammatory effect of visnagin in lipopolysaccharide-stimulated BV-2 microglial cells, Arch. Pharmacal Res., 33, 1843 (2010).

20. Khater, S. I., Kandil, S. A. and Hussien, H. Preparation of radioiodinated khellin for the urinary tract imaging, J. Radioanal. Nucl. Chem., 295, 1939 (2013).

21. Abd-Elzaher, M. M., Moustafa, S. A., Mousa, H. A. and Labib, A. A. Synthesis and biological activity of a ferrocenyl ligand derived from thiophenol and its coordination with some transition metals, Monatsh. Chem., 143, 909 (2012).

22. Abd-Elzaher, M. M., Moustafa, S. A., Labib, A. A., Mousa, H. A., Ali, M. M. and Mahmoud, A. E. Synthesis, characterization and anticancer studies of ferrocenyl complexes containing thiazole moiety, Appl. Organomet. Chem., 26, 230 (2012).

23. Fouda, M. F. R., Abd-Elzaher, M. M., Shakdofa, M. M., El-Saied, F. A., Ayad, M. I. and El Tabl, A. S. Synthesis and characterization of a hydrazone ligand containing antipyrine and its transition metal complexes, J. Coord. Chem., 61, 1983 (2008).

24.Fouda, M. F. R., Abd-Elzaher, M. M., Shakdofa, M. M. E., El Saied, F. A., Ayad, M. I. and El Tabl, A. S. Synthesis and characterization of transition metal complexes of $\mathrm{N}^{\prime}$-[(1,5-dimethyl-3-oxo-2phenyl-2,3-dihydro-1H-pyrazol-4-yl)methylene] thiophene-2-carbohydrazide, Transition Met. Chem., 33, 219 (2008).

25. El-Saied, F. A., Shakdofa, M. M. E., El-Tabl, A. S. and Abd-Elzaher, M. M. A. Coordination behaviour of $\mathrm{N}^{\prime 1}, \mathrm{~N}^{\prime 4}$-bis((1, 5-dimethyl-3-oxo-2phenyl-2,3-dihydro-1H-pyrazol-4-yl)methylene) succinohydrazide toward transition metal ions and their antimicrobial activities, Main Group Chem., 13, 87 (2014).

26. El-Saied, F. A., Abd-Elzaher, M. M., El Tabl, A. S., Shakdofa, M. M. E. and Rasras, A. J. Synthesis, physicochemical studies and biological evaluation of unimetallic and heterobimetallic complexes of hexadentate dihydrazone ligands, Beni-suef Uni. J. Basic and Appl. Sci., 6, 24 (2017).

27. Nohara, A., Ishiguro, T. and Sanno, Y. A novel conversion reaction of 4-oxo-4H-1-benzopyran3-carboxaldehydes to 3-substituted-5-(2-
hydroxybenzoyl)-2(1H)-pyridones, Tetrahedron Lett., 15, 1183 (1974).

28. Hishmat, O. H., EI-Naem, S. I., Magd-El-Din, A. A., Fawzy, N. M. and El-Aal, A. S. A., Egypt J. Chem., 43, 87 (2000).

29. Eiden, F. and Schünemann, J. Darstellung und Reaktionen von 6-Acylkhellin-Derivaten1), Arch. Pharm., 316, 201 (1983).

30. Eiden, F. and Rademacher, G. Synthese und Reaktionen von 3-Acyl-2-methylthiochromonen1), Arch. Pharm., 316, 34 (1983).

31. Lewis, L. and Wilkins, R. G., 'Modern Coordination Chemistry', Interscience, New York (1960).

32. El-Tabl, A. S., Shakdofa, M. M. E., El-Seidy, A. M. A. and Al-Hakimi, A. N. Synthesis, characterization and antifungal activity of metal complexes of 2-(5-((2-chlorophenyl)diazenyl)-2hydroxybenzylidene) hydrazinecarbothioamide, Phosphorus Sulfur Silicon Relat. Elem., 187, 1312 (2012).

33. Nakamoto, K., 'Infrared and Raman Spectra of Inorganic and Coordination Compounds Part B: Applications in Coordination, Organometallic, and Bioinorganic Chemistry', John Wiley \& Sons INC, USA (2009).

34 El-Tabl, A. S., Shakdofa, M. M. E. and Shakdofa, A. M. E. Metal complexes of $\mathrm{N}^{\prime}$ [2-hydroxy-5-(phenyldiazenyl)-benzylidene] isonicotinohydrazide. Synthesis, spectroscopic characterization and antimicrobial activity, J. Serb. Chem. Soc., 78, 39 (2013).

35. Amin, R. M., Abdel-Kader, N. S. and El-Ansary, A. L. Microplate assay for screening the antibacterial activity of Schiff bases derived from substituted benzopyran-4-one, Spectrochim. Acta Part A Mol. Biomol. Spectrosc., 95, 517 (2012).

36. Geary, W. J. The use of conductivity measurements in organic solvents for the characterisation of coordination compounds, Coord. Chem. Rev., 7, 81 (1971).

37. Rageh, N. M., Mawgoud, A. M. A. and Mostafa, H. M. Electronic spectra, solvatochromic behaviour, and acidity constants of some new azocoumarin derivatives, Chem. Pap., 53, 107 (1999).

38. Gup, R. and Kirkan, B. Synthesis and spectroscopic studies of copper(II) and nickel(II) complexes containing hydrazonic ligands and heterocyclic coligand, Spectrochim. Acta Part A Mol. Biomol. Spec-

Egypt. J. Chem. 61, No.2 (2018) 
trosc., 62, 1188 (2005).

39. Sarigul, M., Erkan Kariper, S., Deveci, P., Atabey, H., Karakas, D. and Kurtoglu, M. Multi-properties of a new azo-Schiff base and its binuclear copper(II) chelate: Preparation, spectral characterization, electrochemical, potentiometric and modeling studies, J. Mol. Struct., 1149, 520 (2017).

40. Lever, A. B. P., 'Inorganic Electronic Spectroscopy', Elsevier Science, Amsterdam (1984).

41. Jadeja, R. N. and Shah, J. R. Studies on some oxovanadium(IV) complexes of acyl pyrazolone analogues, Polyhedron, 26, 1677 (2007).

42. Mohamed, G. G., Omar, M. M. and Hindy, A. M. M. Synthesis, characterization and biological activity of some transition metals with Schiff base derived from 2-thiophene carboxaldehyde and aminobenzoic acid, Spectrochim. Acta Part A Mol. Biomol. Spectrosc., 62, 1140 (2005).

43. Gao, E., Bi, S., Sun, H. and Liu, S. Transition metal complexes of the benzoin Schiff base of S-benzyldithiocarbazate, Synth. React. Inorg. Met-Org. Chem., 27, 1115 (1997).

44. Anitha, C., Sheela, C. D., Tharmaraj, P. and Johnson Raja, S. Synthesis and characterization of VO(II), $\mathrm{Co}(\mathrm{II}), \mathrm{Ni}(\mathrm{II}), \mathrm{Cu}(\mathrm{II})$ and $\mathrm{Zn}$ (II) complexes of chromone based azo-linked Schiff base ligand, Spectrochim. Acta Part A Mol. Biomol. Spectrosc., 98, 35 (2012).
45. Thimmaiah, K. N., Lloyd, W. D. and Chandrappa, G. T. Stereochemistry and fungitoxicity of complexes of p-anisaldehydethiosemicarbazone with $\mathrm{Mn}(\mathrm{II}), \mathrm{Fe}(\mathrm{II}), \mathrm{Co}(\mathrm{II})$ and $\mathrm{Ni}(\mathrm{II})$, Inorg. Chim. Acta, 106, 81 (1985).

46. Chohan, Z. H., Arif, M., Shafiq, Z., Yaqub, M. and Supuran, C. T. In vitro antibacterial, antifungal \& cytotoxic activity of some isonicotinoylhydrazide Schiff's bases and their cobalt (II), copper (II), nickel (II) and zinc (II) complexes, J. Enzyme Inhib. Med. Chem., 21, 95 (2006).

47. Chohan, Z. H., Pervez, H., Rauf, A., Khan, K. M. and Supuran, C. T. Isatin-derived antibacterial and antifungal compounds and their transition metal complexes, J. Enzyme Inhib. Med. Chem., 19, 417 (2004).

48. Kulkarni, A. D., Patil, S. A. and Badami, P. S. SNO donor Schiff bases and their Co(II), Ni(II) and $\mathrm{Cu}(\mathrm{II})$ complexes: Synthesis, characterization, electrochemical and antimicrobial studies, J. Sulfur Chem., 30, 145 (2009).

49. Kulkarni, A., Avaji, P. G., Bagihalli, G. B., Patil, S. A. and Badami, P. S. Synthesis, spectral, electrochemical and biological studies of $\mathrm{Co}(\mathrm{II})$, $\mathrm{Ni}$ (II) and $\mathrm{Cu}$ (II) complexes with Schiff bases of 8-formyl-7-hydroxy-4-methyl coumarin, J. Coord. Chem., 62, 481 (2009).

(Received 4/12/2017; accepted 8/2/2018)
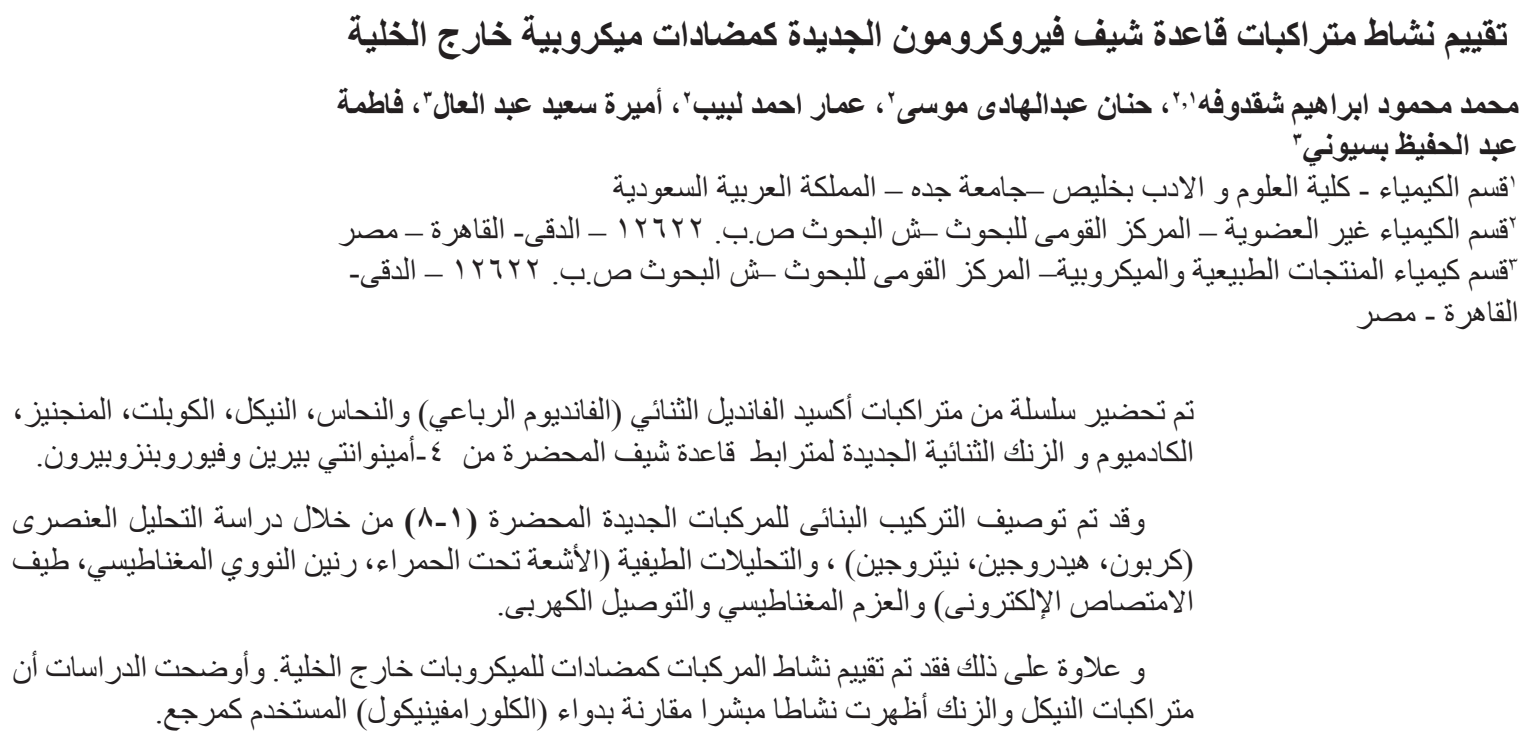